\title{
Gene therapist accused of fraud to seek redress in German court
}

[MUNICH] Germany's most notable case of alleged scientific fraud took a new turn last week with the announcement that one of the two accused scientists intends to sue investigators in the case for DM10 million (US\$5.6 million), in compensation for damage to his career. At the same time, a new inquiry has alleged that both researchers also faked data earlier in their careers.

Friedhelm Herrmann, a leading gene therapist at the University of Ulm in BadenWürttemberg, has denied being involved in the fraud, which is alleged to have involved fabrication of data in more than 30 papers in molecular medicine (see Nature 387, 750; 1997). His former colleague, Marion Brach, has admitted forging data in some papers, and claimed that Herrmann was aware of the fraud. Both researchers have been suspended from their posts.

Last week, Holger Zuck of the Stuttgartbased law firm Zuck and Quaas, who is representing Herrmann, announced that they intended to sue both Guido Adler, the dean of medicine at the University of Ulm, who initiated inquiries into the case, and members of the five investigative commissions set up subsequently at the universities of Ulm, Berlin, Lübeck and Freiburg. Zuck asserts that Herrmann's career has been ruined, and that this has

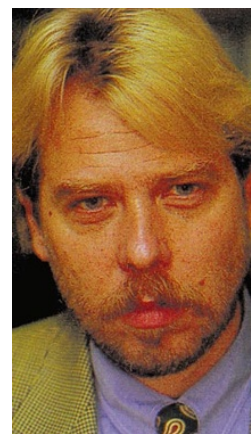

caused him serious financial damage - as a full professor, 47year-old Herrmann would have been earning about DM500,000 (US $\$ 278,000$ ) a year.

Ulm university has reacted calmly to talk of legal action. "We have taken note of the defence's strategy. Herrmann: plans to But the investigation sue for damages. commission definitely sees things differently and there is no need for us to take further steps," says Adler.

The lawyers also announced that they intend to sue the Deutsche Forschungsgemeinschaft (DFG), Germany's main grant-giving body, for the retraction of allegations by a DFG inquiry committee that two grants awarded to Brach and Herrmann were, "in at least two cases", either obtained fraudulently — through making grant applications based on fabricated papers - or used directly in relation to fabricated publications. The DFG says that this occurred at least to some extent, although it has yet to investigate the matter fully.

\section{Accidents prompt Los Alamos closure}

[SAN FRANCISCO] The US Los Alamos National Laboratory in New Mexico is to shut down a nuclear weapons research facility for six months following a spate of accidents. A \$175-million refurbishment will be carried out during the shutdown.

The Chemistry and Metallurgy Research facility, which has 350 staff, covers 550,000 square feet and houses laboratories for analytical chemistry and metallurgical studies on plutonium and other nuclear materials. Work at the facility supports programmes in nonproliferation and nuclear safeguards, weapons and stockpile surveillance, nuclear materials technologies, and waste treatment and minimization.

The shutdown was ordered by Alex Gancarz, who took over as the facility's safety director on 2 September. He said he was concerned that employees were not adhering properly to safety procedures. "I'm ordering this suspension of normal operations now so we don't see someone get hurt," Gancarz said in a statement.

The facility's safety record is hardly exemplary. In the past six months alone, 16 staff have been exposed to radioactivity. An investigation following an explosion in the facility's building last autumn criticized management and staff for failing to follow elaborate work controls and qualityassurance plans.

Last summer, after several accidents at Los Alamos that resulted in one death and an employee being left in a coma, Sig Hecker, the director of Los Alamos, shut down all operations temporarily. Earlier this year, a federal investigation found 32 violations of safety standards during construction work on a nuclear weapons facility there.

Gancarz said he planned to have research reviewed to ensure it complied with safety procedures, and to have personnel properly trained in safety regulations. The \$175million refurbishment will upgrade electrical, ventilation, seismic safety and other systems. Staff will not be laid off during the closure, but will be redeployed in improving safety practices and infrastructure.

Sally Lehrman
The DFG grant committee has also asked the DFG senate to ban Herrmann from all DFG committees. At the same time, the DFG says it intends to question scientists who received DFG funding and who worked in Herrmann and Brach's groups. Establishing their personal contribution to suspect publications "is absolutely necessary to protect those scientists who got involved in the affair through no fault of their own from possible damages in their career", says Eva-Maria Streier, the spokeswoman for the organization.

Herrmann is also contesting the decision of the Baden-Württemberg science ministry to begin legal proceedings to strip him of his status as a civil servant. In a 22page statement submitted to the ministry, Herrmann's lawyers deny all charges of fraud, arguing that Herrmann was only the "senior author or translator" of the allegedly fabricated papers and that all responsibility lies with Brach. Herrmann had no motive to commit fraud, it asserts, given that, "unlike Brach, he had already reached the top of his career ... Ms Brach ... is the only person who could have had a motive at all [obtaining the post of full university professor]", it goes on to allege.

Meanwhile, a new investigation focusing on the period 1988-93, when Herrmann and Brach were working at the University of Freiburg, has brought to light a further 12 papers suspected of containing fabricated data. However, the investigation, by a Freiburg committee headed by Albin Eser, director of the Max Planck Institute for International Criminal Law, found no proof of collusion by other scientists in the group.

Nonetheless, the report asserts that Roland Mertelsmann, who is head of the clinical department of the University of Freiburg, and who co-authored 25 of the suspect publications, must "bear a share of the responsibility for scientific fraud in his department". Mertelsmann declined to comment on events at Freiburg, arguing that this would be inappropriate given that the Baden-Württemberg ministry of science had not yet issued a formal statement on the matter.

In response to what is Germany's largest post-war incident of research fraud, representatives of the main scientific organizations and foreign scientists will meet next week to discuss standards of experimental scientific work, and to compare mechanisms for autoregulation in Germany with those elsewhere.

QuirinSchiermeier 